\title{
WORD CHANGE IN WORDPLAY BY TEENANGERS ON TWITTER: A SOCIOLINGUISTIC STUDY
}

\author{
Rahmita Egilistiani \\ Universitas Pamulang, Banten \\ dosen01439@unpam.ac.id
}

Abstract 
There are always a new slang language that teenagers use from period to period. New slang language that teenagers use are word change. Word change is usually used by teenangers because of following the previous speaker and make it as a habit language for them. Word change in wordplay patterns on Twitter will be researched that written by teenagers. Qualitative method is used in this research. Documentary study is used and the data written desciprtively. The teenagers between 13-22 years old who write documentation on Twitter using word change in wordplay are the main data in this research. Basic and advanced technique are used in describing the data. There are 8 wordplay patterns with word change revealed in 8 data teenagers writing using wordplay in Twitter.

Keywords: teenagers language, wordplay 


\section{INTRODUCTION}

People communicate to have a connector that called language. In lingusitics, Kushartanti et al (2009:3) said that to collaborate, communicate and identify ourselves with a social grup we need language as a sound system. Environment can change of how people communicate the language with someone. Sapir - Whorf hypothesis in Sumarsono (2010: 25-26) said there are four refutation about language that can change the human view about the environment which are: (1) material science condition can be reflected in dialect where society live, along these lines, the earth can impact the dialect society itself, more often than not in dictionary or its vocabulary; (2) social condition, can be reflected in dialect and regularly affected in the vocabulary structure, the general public improvement additionally caused society structure and foundations changed; (3) the layers of primitive and position likewise brought an affected up in dialect; and (4) social society esteem can be affected in the public eye dialect itself.

These days, individuals today are more fascinating impart in the internet than this present reality. This additionally occurred by adolescents. The more somebody has collaboration in the internet will make them utilizing increasingly casual dialect one of them is a slang dialect. Presently, slang dialect has its assortment. One of the slang dialect utilized by youngsters is word change. The raised word change utilized by teenagers is one of the dialect play. Word change created by some teenagers is a language play that is created by themselves and followed by other teenangers and become hits to be a new slang language.

A great deal of online life utilized by everybody like Facebook, Twitter, Path and so forth made teenagers make them need to refresh their dialect rise in their circle. Word change in young people dialect shows up and utilized by teenagers and written in internet-based life. After Facebook showed up, adolescents dynamic utilizing another online life like Twitter as a holder to speak with everybody. In spite of the fact that a ton of online networking seems these days, a few adolescents utilized word change discussion in Twitter. This is on the grounds that Twitter is a place that individuals can do a discussion with 140 characters. Along these lines, a Twitter discussion can't be too long like another web-based life. This concise discussion makes adolescents use word change increasingly basic and straightforwardly to the point regarding the matter.

A young person is an individual that can be impacted in the current condition. word change that generally composed of young people in Twitter is a word that consolidates word change with a standard word in a sentence. In view of the issue over, the scientist is intrigued to break down a word change in pleasantry design composed of teenagers on Twitter. The purpose of this research is to analyze word change in wordplay patterns written by teenagers on Twitter.

\section{Teenagers Language}

Today teenagers dialects change. The quantities of new dialects that popping up utilized by teenagers, make genuine Indonesian dialect disregarded and vanquished with a feeling of pride and need to connect with human advancement time that pursued. The age that more increment influences a social tongue in dialect to can likewise be changed, just as teenagers. Sumarsono (2010: 26) said that gathering of individuals that permit social vernacular will, at any rate, caused give its very own shading in the gathering.

A few varieties in teenagers dialect don't get away from the nearness of slang dialect. This variety of teenagers dialect can 
make an exceptional term that just there gathering who knows. Slang word as indicated by Keraf (2001: 98) is a casual word that organized ordinarily in a discussion. This slang dialect some of the time can be spoken accidentally both in composed or oral by the teenagers in fluctuating their dialect.

Here and there, teenagers dialect variety is wrapped regularly and can incorporate into jargon. Jargon, as indicated by Keraf (2001: $107)$ is a unique dialect. Normally this unique word has a reason to discuss mystery. Spolsky (2003:33) likewise clarified that unique jargon is exhibited to give a name of another idea. So, a jargon in teenagers language variation can make a limit that means "this is my group, if you don't understand our group language, so you are not included in my group."

\section{Wordplay}

Wordplay as per Sudjana and Rohmadi (2006: 58) showed up in light of the fact that there is a dialect misuse like syllables, some portion of words, word and so on so the grammatic, semantic and pragmatics component not as it ought to be. The presence of dialect play in slang dialect that is increasingly utilized by a few young people caused youngsters dependably need to discover their personality. One of the variations in dialect play exists in slang dialect.

Slang dialect is a dialect that is utilized by young people and furthermore utilized by grown-ups in a minority. One of current slang dialect that raises a dialect measurement resembles talking ruined like child talk. In etymology, a ruined dialect that is being one of the slang dialects these days is certifiably not a decent dialect variety. This is clarified by Sudjana and Rohmadi (2006: 72) that ruined dialect variety or like infant talk is a dialect issue that is associated with a mental viewpoint. Slang dialect comprises more that one, one of them as per Sumarsono (2010) is as following:

\section{Interpolation of $v$ consonant + vowel}

Interpolation of $\mathrm{v}$ consonant + vowel is showed up before 50's among the young people (Sumarsono, 2010). The vowel that existed behind $\mathrm{v}$ is adjusted with syllables vowel that embedded. V consonant + vowel is put behind each syllable, either in neighborhood dialect just as in Indonesian. Example:

Jauh $($ far $)=j a+u h \rightarrow(j a+v a)+(u+v u+$ h) $\rightarrow$ javauvuh

Rusak (broken) $=r u+s a k \rightarrow(r u+v u)+$ $(s a+v a k) \rightarrow$ ruvusavak

After $\mathrm{v}$ consonant + vowel showed up, the embed in slang dialect with comparative recipe likewise shows up with $\mathrm{p}$ consonant + vowel and g consonant + vowel.

\section{Replacement of the final term by -sye}

The replacement of the final syllable with the -sye appeared in the sixties (Sumarsono, 2010). The word taken is the first syllable only, the other tribe is removed and replaced with -sye. Example:

Key $($ Kunci $) \rightarrow$ kunsye

Eat (Makan) $\rightarrow$ maksye

\section{Reverses the phoneme in a word (multiform range)}

This phoneme reversing language appeared in 1960 among tenaagers in Malang (Sumarsono, 2010) and eventually spread to other areas to the Indonesian territory. Basic words can be from the local language or Indonesian language. The words are read in the order of the phonemes from the back and are read in reverse (Java = walikan). Example:

Eyes $($ Mata $) \rightarrow$ atam

Sari (one of indonesian girls' name) $\rightarrow$ iras 
In Sundanese, this variety of walikan language is also used by adolescents. Example:

Nu gelo $\rightarrow$ olegun ( crazy person)

Ripuh $\rightarrow$ hupir (hard)

In a foreign language spoken with the Sundanese dialect lately is also often used by teenagers. Example:

Slow $\rightarrow$ selow $\rightarrow$ woles

\section{Variations of the walikan variety model}

This inverse multiplier reversal model is a continuous range of variables. Thus, the reversed word is inserted by certain sounds or certain sounds in the word are changed. Example:

No (Tidak) $\rightarrow$ kadit $\rightarrow$ kadodit

Healthy (Sehat) $\rightarrow$ tahes $\rightarrow$ tahohes

The morpheme insertion \{to the in the middle of the syllable

The morpheme insertion \{to the in a syllable appears when an instant noodle advertisement declares the word "so to the to" in the ad. After such words appear, the language becomes popular and add it up with other words. Example:

Delicious $($ Enak $) \rightarrow E+n a k=E+$ to the + nak

Hungry $($ Lapar/Laper $) \rightarrow \mathrm{La}+$ per $=\mathrm{La}+$ to the + per

The addition of phoneme $d e .$. fen in every syllable

Users of this slang language are certain people creating their own group language formulas. this word is taken on every syllable and added $\boldsymbol{d e}$ before syllable and $\boldsymbol{f e n}$ after syllable. Example:

Style (Gaya) $G a+y a=$ degafen + deyafen Sleep (Tidur) $t i+$ dur $=$ detifen + dedurfen

\section{The change of 'Kali' an informal} additional word of the sentence
Lately, many teenagers or slang people in big cities talked to their peers using sentences with the last word in the modification. This word changes shape by changing vowels $/ a /$ and $/ i /$ at times with $/ e /$. The second $e$-vowel is mostly added more than one. Kali consists of two syllables $/ k a$ $+l i /$ it made change the syllable becomes keles $\rightarrow / k e+$ les /. The second syllable is also other than changed from $/ i /$ to $/ e /$ but sometimes there is a change from $/ i /$ become leu/that is /ke + leus /

Kali $\rightarrow$ kelees or keleus

Example long sentence: Gak gitu juga keleees (It's not that i mean)

\section{Phrase abbreviation to be a word}

The slang language also exists which is a shortened phrase into a word. The abbreviated phrase is meant to make it easier for teenagers to mention it. Example:

Masbuloh? $\rightarrow$ Masalah buat lo? (Problems with you?)

Sukri $\rightarrow$ suka riweuh (hectic with themshelves)

Heri $\rightarrow$ heboh sendiri (excited)

Change the two vowels on the word to /i/

The change of vowels into diverse into /i/ occurs on the word "banget". In the word "banget", the following vowels are the letters ' $a$ ' and 'e'. But, adolescents today change all the vowels in the word "banget" become "bingit".

The example in the sentence:

"Dia itu orangnya engga bingit"

"He's not in my type"

"Bingit" in the sentence above has the meaning of the word "banget".

\section{METHOD}

Based on the purpose of this research; which is to analyze word change in wordplay patterns by teenangers written on Twitter, so this research is included in qualitative 
research using descriptive with documentary study. Sudaryanto (1992: 62) explained that the research using descriptive method is done just dependent on existed actuality so it created a dialect as a representation: a genuine clarification. The used of documentary method in this research is increasingly centered around finding the data as notes. This is similar with Arikunto (2002: 206) that documentary method is information look about things or variable as notes, transcript, paper books, magazine, and so on.

There are a few stages that the researcher did to gather the data. A few stages that taken in this research are as per the following:

1. Implement literary sudy to read and learn sources of references in this research in the form of books, thesis, and research journal related to this research.

2. Find a data source from Twitter that composed by teenagers with using wordplay.

3. Note all the data and sentences composed by teenangers on Twitter. This is done after getting some data in Twitter that composed by teenagers.

4. Clasify the data in accordance with the research purposes based on every wordplay category written. The data clasification is made in some classification based on type of wordplay written by teenangers on Twitter in.

5. Analyze the data to find types of word arrangement and rule of word arrangement in the teenagers writing with their wordplay. The analyze of data is a stage of exhibiting data in informal and formal since it is depicted with words, signs, and images.

6. Conclude all the research result that has been done after doing analyze the data.
7. Arrange the research report directed with definition arrange as indicated by relevant arrangements.

\section{DISCUSSION}

A good and proper word in the Indonesian language should be arranged based on Indonesian Dictionary. However, in reality, some teenagers use social media like Twitter to write tweets by changing one of the words in the sentence. Patterns on the change of words on Twitter are included in the free (inconsistent) pattern. This inconsistent pattern exists because every word changed on Twitter does not have various formulas and changes without the applicable formula. The data of this research can be in the form of words with an extension meaning, changes in words by means of inversion (words reversed) or changes in words by changing the vocals. Some word changes are based on the research data found as follows:

1. RafiR@Rafi_Raihan12.

Siapa we fir meni_kepo: $D=)$ ) $R T^{\prime \prime}$,MfirqiR:@,dzikrihernandez siapa jik?"

2. RafiR@Rafi_Raihan12 Siip (y)RT"@daffasinyong: @,Rafi_Raihan12 FUCK lah woles woles $=$ ))

3. Kania_as@kania_as . $R T=)$ )"@DOBlPARK: Ceritanya nina obob adalah the conjuring versi indonesia."

4. Sorry For Spam a,Gabby18 Feb 19 Oct 2013 describe 8-8-Des baraleg? :3 sip okay. Baraleg adalah singkatan $d r$ BARudak dALapan EiGht wkwk jauh bingit ya.- 
5. Syahdamusyaffa@Syahda_200901. Pingin modus modusan lagii :(

6._Alyda@AlydaaaNA. prastawa gokil-_-

7._RizkaAlifia@Rizka_Alifiiia . Engga jugakeles"@,Viccent22: Jutek itu seksi."

8. @alfionitaaa. $A$ : mati mah gimana allah, lain kumaha roko!|B : tapi kan meroko mempercepat kematian? |A: naa ari mnh meni sotoy! $\mid B$ : nyalah:v

The data in this sub-section consists of only one word in every conversation on Twitter. Some analyzes for wordplay in word changes are as follows: Data (1) written by @ Rafi_Raihan12 is a Twitter conversation with a friend. The word to be researched in data (1) is as follows:

(1) kepo

Kepo is a word that is widely used by teenagers or adults lately. This word is widely used with various meanings. But the general meaning of this word kepo is 'want to know the affairs of others' or 'find out the affairs of others by scratching his own personal data' the abbreviation of Kepo is Knowing Every Particular Object.

Kepo $\rightarrow$ want to know the affairs of others

$$
\rightarrow \text { find out the affairs of }
$$

The same data written by @ Rafi_Raihan12 writes a sentence with one of the changed words. The word is as follows:

\section{(2) woles (slow)}

Woles is a word on various lines. One of the words written by @ Rafi_Raihan12 is a form of annoyance that makes itself to further calm itself by saying "woles woles". The variety of walikan is the word that reverses the way of reading. The variety of walikan by Sumarsono (2010: 152) is read in the order of the phoneme from behind. This Walikan comes from the Javanese language which means inverse. Actually, woles is a word which if reversed becomes an English word meaning "quiet". This can be seen from the construction as follow:

Slow $\rightarrow$ selow $\rightarrow$ woles

Selow is an English word commonly spoken by Indonesians by adding phoneme $/ e /$ to the original word 'slow'. The teenagers make the word 'selow' was turned into 'woles' and became the common language used in social media one of them Twitter. So, the word 'calm' in the present era has been replaced with many words 'woles' both written and oral.

Similar to data (2), one of the word changes in data (3) written by @DOBIPARK commented by@kania_as with emoticons laughing is a walik verbal. The word obob here is a word that is reversed with the origin of the word bobo. Can be seen from the following construction:

(3) $o b o b$

sleep $($ Bobo $) \rightarrow o b o b$

Words that include these walikan varieties are used by teenagers in social media such as Twitter to make people who read the confusion using a strange language that is in fact involuntarily made by turning the word. Data (4) written by @Gabby18 is a word that changes the phoneme /a/ and /e/ to /i/ change the word here including into the word change by changing the vowel. This can be seen from the construction as follows:

\section{(4) bingit}

banget $\rightarrow$ bingit

Bingit word arise due to the influence of one of the teen soap operas that aired on one private television in 2013. In an opera scene, the conversation between the teenagers was expressed with many raises the word bingit. From then on, the word bingit became 
widely used by teenagers even now one of them in the media Twitter.

The data (5) written by @Syahda_200901 consists of a single word that changes in the tweets that she writes. The words analyzed are as follows:

\section{(5) modus}

Modus according to Purwadarminta (1986: 653 ) is defined as a method. In the sense of linguistic study, modus can be interpreted as a verb that expresses a psychological atmosphere associated with deed according to the speaker's interpretation of what it says. Modus word written by @Syahda_200901 is a word that has a different meaning from the actual meaning. The word consolation of this modus belongs to a change of words with an expanded meaning. The teenager who writes the phrase "Pingin modus modusan lagi" This does not mean want to feel again some way, because if it is interpreted with the real meaning, the sentence means "want to feel the way again".

Data (6) written by @AlydaaNA consists of one word that has changed. The words analyzed are as follows:

(6) gokil

Gokil is a slang language that has a crazy meaning. Crazy in this case does not mean a psychological condition of a person who is less sane but rather refers to the condition where the event or someone doing something extraordinary, unexpected, funny (often joking) and great. This gokil word has been widely used by some teenagers years ago and remain widely used today. The word gokil written by @AlydaaaNA with the phrase "prastawa gokil _._" has the meaning that her friend named Prastawa is a funny person (often joking).

Gokil belongs to this changed word is a progem word which according to Sumarsono (2010: 154) comes from a thug language that has the following formula: a. each word is taken three phonemes (consonant groups are considered one) first: crazy (gila) becomes gil;

b. the form is inserted by -ok-, behind the first phoneme (or phoneme group), into gil.

gokil

$$
\text { crazy }(\text { gila }) \rightarrow \text { gil } \rightarrow g-o k-i l \rightarrow
$$

So, the last vowel or consonant that follows the first three phonemes is not included.

The data (7) written by @Rizka_Alifiia has one word that changes. The words to be analyzed are as follows:

(7) keles

Keles is a word that replaces the word times. This keles word first appeared in one of the teen soap operas that aired on a private television station at the end of 2013. One of the scenes featured a very sassy young woman who was too sloppy who always mentioned the keles at the end of her talk. Starting from that moment, the word keles became the new legendary slang until now. Keles is a word that has a vocal change to the word "kali". All vowels in the word "kali" are changed to /e/. Thus, whose origin has different vowels is changed to have the same vowel.

\section{Maybe (Kali) $\rightarrow$ keles}

The sentence written by @Rizka_Alifiiia who responded to the tweet of his friend @ Viccent22 was a response that expressed disapproval of the statement that his friend wrote on Twitter. This can be seen from her writings "Engga juga keles" (a) Viccent22: Jutek is sexy. "When his friend stated that the person who is jutek was sexy then he responded with " Engga juga keles". Because the word keles is becoming a legendary slang word, then the young woman joined in changing the word "kali" into keles in Twitter.

Data (8) written by @Alfionitaaa consists of a single word that changes. The words analyzed are as follows: 
(8) sotoy

Sotoy is a slang word originally derived from two words knowingly. The existence of the word sotoy is used to facilitate the language users in a practical word. The word sotoy includes words that have changed. This can be seen from the know-it-all who is not much used though by teenagers and always replaced with the word sotoy. Tweet written by @Alfionitaaa is a conversation she made herself and uses the word sotoy in it. The tweet she wrote was "A: naa ari mnh meni sotoy!".

\section{CONCLUSION}

From the eight data in this section, it can be categorized that the free word pattern (inconsistent) that makes a word change written by teenagers is divided into four parts. The categories are presented in the table as follows:

Table 1. Wordplay patterns in a word change

\begin{tabular}{c|l|l|l}
\hline No & $\begin{array}{l}\text { Pattern } \\
\text { Change of } \\
\text { Meaning }\end{array}$ & Word & \multicolumn{1}{|c}{ Meaning } \\
\hline 1. & $\begin{array}{l}\text { Change the } \\
\text { word by } \\
\text { replacing the } \\
\text { new word }\end{array}$ & $\begin{array}{l}\text { Gokil } \\
\text { Sotoy }\end{array}$ & $\begin{array}{l}\text { Gila } \text { (crazy) } \\
\text { Sok tahu } \\
\text { (Knowledgeabl } \\
\text { y) }\end{array}$ \\
\hline 2. & $\begin{array}{l}\text { Change } \\
\text { walikan } \\
\text { varieties } \\
\text { word }\end{array}$ & $\begin{array}{l}\text { Woles } \\
\text { Obob }\end{array}$ & $\begin{array}{l}\text { Selow (Slow) } \\
\text { Bobo (sleep) }\end{array}$ \\
\hline 3. & Change the & Bingit & Banget (sure) \\
\hline
\end{tabular}

\begin{tabular}{|c|c|c|c|}
\hline & $\begin{array}{l}\text { word by } \\
\text { changing the } \\
\text { vowel }\end{array}$ & Keles & Kali (maybe) \\
\hline 4. & $\begin{array}{l}\text { Changes in } \\
\text { words that } \\
\text { have an } \\
\text { extension of } \\
\text { the meaning }\end{array}$ & Керо & $\begin{array}{ll}- & \text { Finding } \\
\text { other } \\
\text { people's } \\
\text { problem } \\
\text { - Abbreviation } \\
\text { s }\end{array}$ \\
\hline & & Modus & 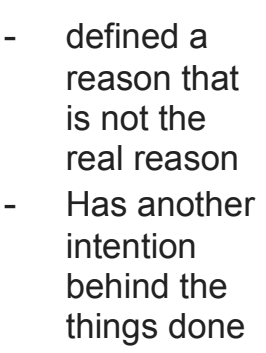 \\
\hline
\end{tabular}

REFERENCES

Arikunto, Suharsimi (2002) Prosedur Penelitian: Suatu Pendekatan Praktek. Jakarta: Rineka Cipta.

Keraf, Gorys (2001) Diksi dan Gaya Bahasa. Jakarta: Gramedia Pustaka Utama.

Kushartanti et al. (2009) Pesona Bahasa: Langkah Awal Memahami Linguistik. Jakarta: GramediaPustaka Utama.

Spolsky, Bernard (2003) Sociolinguistics. New York: Oxford University Press.

Sudaryanto (1992) Metode Linguistik: Ke Arah Memahami Metode Linguistik. Yogyakarta: Gadjah Mada University Press.

Sumarsono (2010) Sosiolinguistik. Yogyakarta: Sabda.

Sudjana, I Dewa Putu \& Muhammad Rohmadi (2006) Sosiolinguistik: Kajian Teori dan Analisis. Yogyakarta: Pustaka Pelajar 
